\title{
PEMBAYARAN PAJAK SARANG BURUNG WALET DI KANTOR BADAN PENGELOLAAN PENDAPATAN DAERAH KABUPATEN SINTANG
}

\author{
Syekh Mochsin \\ Fakultas Ilmu Sosial dan Ilmu Politik Universitas Kapuas Sintang \\ Jl. Y.C. Oevang Oeray No 92 Baning Kota \\ Email: syekhmochsin@gmail.com
}

\begin{abstract}
Abstrak : Penelitian ini adalah Pelayanan Pembayaran Pajak Sarang Burung Walet di Kantor BAPPENDA (Badan Pengelolaan Pendapatan Daerah) Kabupaten Sintang. Dengan ruang lingkup Penelitian, Mekanisme Pelayanan, Tatacara Pendataan dan Pendaftaran, Sumber Daya Manusia. Metode yang di pergunakan dalam Penelitian ini adalah Metode Deskriptif Kualitatif. Subjek dalam penelitian ini adalah berjumlah Empat orang, yang terdiri dari: Kepala Kantor BAPPENDA Kabupaten Sintang, Pegawai Bidang pendataan pajak sarang burung walet di Kantor BAPPENDA Kabupaten Sintang, Pegawai Pelayanan penerimaan Pajak, Subjek Pajak/pembayar pajak. Pengumpulan data-data di lakukan dengan teknik Wawancara dan Observasi juga dengan Studi Dokumentasi.
\end{abstract}

Kata Kunci : Pembayaran, Pajak, Sarang, Burung, Walet.

Melalui otonomi Daerah diharapkan daerah akan lebih mandiri dalam menentukan kegiatannya untuk memajukan daerah. Dalam Undang-Undang Nomor 9 tahun 2015. tentang Pemerintah Daerah telah dibuka saluran baru bagi pemerintahan Provinsi dan Kabupaten/Kota untuk mengambil tanggung jawab yang lebih besar dalam pelayanan umum kepada masyarakat untuk mengatur dan mengurus rumah tangganya sendiri.

Agar daerah dapat menjalankan kewajiban dengan sebaik-baiknya, Pemerintah Daerah sangat memerlukan sumber keuangan daerah. Semakin besar keuangan daerah, maka akan semakin besar pula kontribusinya terhadap penyelengaraan usahausahanya dalam bidang keamanan, ketertiban umum, sosial, kebudayaan, kesejahteraan, serta pelayanan umum kepada masyarakat.

Pendapatan Asli Daerah adalah penerimaan yang diperoleh daerah dari sumbersumber dalam wilayahnya sendiri yang dipunggut berdasarkan peraturan Perundang-undangan yang berlaku.Undang-undang Nomor 33 tahun 2004 Tentang Perimbangan keuangan pusat dan daerah dalam pasal 157, menyebutkan tentang sumbersumber Pendapatan Daerah meliputi : 1. Pendapatan Asli Daerah meliputi : a. Hasil Pajak Daerah b. Hasil Retribusi Daerah c. Hasil pengelolaan kekayaan daerah lainnya yang dipisahkan. 2. Dana Perimbangan yaitu dana yang bersumber dari APBN yang di alokasikan kepada Daerah untuk kebutuhan daerah melaksanaan desentralisasi. 3. Lain-lain Pendapatan Asli Daerah yang sah. Semakin besarnya peranan Pendapatan Asli Daerah (PAD) berarti semakin sedikit ketergantungan Daerah terhadap bantuan pusat.

Pendapatan Asli Daerah (PAD) digunakan untuk membiayai pengeluaran daerah seperti : pengeluaran rutin dan pengeluaran pembangunan.
Dari hasil penerimaan pajak sarang burungwalet oleh pemerintah digunakan untuk membiayai keperluaan daerah, baik dari segi pembangunan, keamanan, ketertiban lingkungan, dan lain-lain yang berkaitan dengan daerah itu sendiri.

Pajak Sarang Burung Walet adalah pajak atas kegiatan pengambilan dan atau pengusahaan sarang burung walet. Dasar Pengenaan Pajak adalah nilai jual sarang burung walet. Tarif Pajak ditetapkan 10\%. Besarnya Pajak Terutang dihitung dengan cara mengalikan Dasar Pengenaan Pajak dengan tarif Pajak.

Supaya perkembangan daerah menjadi maju, dengan ini daerah harus memiliki keunggulan yang dapat dihandalkan. Salah satu Pendapatan Asli Daerah (PAD) diharapkan menjadi salah satu sumber pembiayaan penyelengaraan pemerintah dan pembangunan daerah untuk meningkatkan dan meratakan kesejahteraan masyarakat adalah dari Pajak Daerah. pajak daerah telah menjadi sumber penerimaan yang dapat di handalkan bagi daerah.

Definisi Pajak Sarang Burung Walet yang selanjutnya disebut pajak adalah pajak atas kegiatan pengambilan dan/atau penguasaan sarang burung wallet, Burung Walet adalah satwa yang termasuk marga collocalia, yaitu collocalia fuchliap haga, collocalia maxina, collocalia esculanta, dan collocalia linchi. Obyek Pajak adalah pengambilan dan/atau penguasaan Sarang Burung Walet, dikecualikan dari obyek pajak adalah pengambilan Sarang Burung Walet yang dikenakan penerimaan Negara Bukan pajak (PNBP).Subyek Pajak adalah orang pribadi ataubadang yang melakukan pengambilan sarang burung wallet, Wajib Pajak adalah orang pribadi atau Badang yang melakukan pengambilan dan/atau pengusahaan sarang burung wallet.Dasar pengenaan pajak adalah Nilai Jual Sarang Burung Walet. 
Nilai Jual Sarang Burung Walet dihitung berdasarkan perkalian antara harga pasaran umum Sarang Burung Walet yang berlaku di Daerah dengan volume Sarang Burung Walet.Masa pajak adalah jangka waktu 3 (tiga) bulan kalender yang menjadi dasar bagi Wajib Pajak untuk menghitung, menyetor, dan melaporkan pajak yang terutang.Pajak terutang dalam masa pajak terjadi pada saat pengambilan dan/atau pengusahaan sarang burung wallet.

Sanksi bagi Wajib pajak yang karena kealpaannya tidak menyampaikan SPTPD atau mengisi dengan tidak benar atau tidak lengkap atau melampirkan keterangan yang taidak benar sehingga merugikan keuangan daerah dapat dipidana dengan pidana kurungan paling lambat 1 (satu) tahun atau pidana denda paling banyak 2 (dua) kali jumlah pajak terutang yang tidak dibayar. Wajib pajak yang dengan sengaja menyampaikan SPTPD atau mengisi dengan taidak benar atau tidak lengkap atau melampirkan keterangan yang tidak benar sehingga merugikan keuangan daerah dapata dipidana dengan pidana penjara paling lama 2 (dua) tahun atau pidana denda paling banyak 4 (empat) kali jumlah pajak terutang yang tidak atau kurang dibayar.

Pajak Sarang Burung Walet juga berperan penting dalam meningkatkan Pendapatan Asli Daerah Kabupaten sintang. Mengingat banyak terdapatnya rumah sarang burung walet yang disediakan oleh pengusaha burung walet khususnya di sekitar Pasar Raya Sintang dan Pasar Sungai Durian Sintang yang dalam hal ini memiliki potensi. Berdasarkan Peraturan Daerah Kabupaten Sintang, Nomor 2 Tahun 2011, Tentang Pajak Daerah terutamatentang Pajak Sarang Burung Walet. Burung Walet adalah : satwa liar yang tidak dilindungi, yang termasuk dalam marga Collocaliaadalah spesies burung dari keluarga Apodidae, dari genusCollocalia. Burung ini merupakan jenis burung pemakan serangga kecil yang memiliki habitat di semua tipe hutan, lahan pertanian, perkotaan. Juga di perjelas dalam Peraturan Bupati Sintang Nomor 28 Tahun 2016, tentang Tatacara Pemungutan Pajak Sarang Burung Walet.

Berdasarkan Keputusan Bupati Sintang Nomor 970/2/KEP-DISPENDA/2017, tentang Penetapan harga pasaran umum sarang burung Walet di Kabupaten Sintang. Data tentang Jumlah sarang burung walet yang ada di Kecamatan Sintang 34, Rumahan Sarang burung walet sudut, Sedangkan data jumlah keseluruhan untuk Kabupaten Sintang berjumlah 93, Sarang burung walet sudut. Daftar harga sarang burung walet di Kabupaten Sintang adalah Sarang Burung Walet mangkok (Klasifikasi A), perkilogram Rp.6000.000.-. Sarang burung walet sudut (Klasfikasi B), perkilogram
Rp.4.000.000,-. Sarang Burung Walet retakan (Klasifikasi C), perkilogram Rp. 2.000.000,-. (data di ambil dari Kantor BAPPENDA Kab.Sintang dalam Tahun 2018).

Pajak sarang burung walet juga menjadi handalan Pemerintah Daerah memberikan kontribusinya untuk Meningkat Pendapatan Asli daerah (PAD) mengingat terdapat rumah-rumah pengusahaan Sarang burung walet oleh pengusaha yang di jadikan sebagai Wajib Pajak daerah. Maka penulis merasa tertarik untuk mengambil Judul penelitian ini yaitu, Pelayanan Pembayaran Pajak Sarang Burung Walet di Kantor BAPPENDA (Badan Pengelolaan Pendapatan Daerah) Kabupaten Sintang.

Berdasarkan permasalahan yang ada, maka ruang lingkup penelitian ini adalah Pelayanan Pembayaran Pajak Sarang Burung Walet di Kantor BAPPENDA (Badan Pengelolaan Pendapatan Daerah) Kabupaten Sintang, dengan aspek sebagai berikut:1).Mekanisme Pelayanan, 2)

Tatacara Pendaftaran dan Pendataan. 3)Sumber Daya Manusia

Mekanisme Pelayanan tentu akan memberi makna yang mendasar tentang Alur atau tatacara pengurusan surat menyurat atau perizinan pada kantor pemerintah sebagai pelayanan atau pemberi layanan tentu harus memberikan tatacara pengurusan agar masyarakat bisa mengurus dengan cepat, untuk memperjelas tentang Mekanisme Pelayanan maka terlebih dahulu penulis mengutip pendapat Lorens Bagus.

Menurut Lorens Bagus, (1996: 612-613). Mekanisme Pelayanan adalah sebagai berikut: 1). Mekanisme adalah pandangan bahwa interaksi bagian-bagian dengan bagian-bagian lainnya dalam suatu keseluruhan atau sistem secara tanpa disengaja menghasilkan kegiatan atau fungsi-fungsi sesuai dengan tujuan. 2). Mekanisme adalah teori bahwa semua gejala dapat dijelaskan dengan prinsip-prinsip yang dapat digunakan untuk menjelaskan mesin-mesin tanpa bantuan inteligensi sebagai suatu sebab atau prinsip kerja. 3). Mekanisme adalah teori bahwa semua gejala alam bersifat fisik dan dapat dijelaskan dalam kaitan dengan perubahan material atau materi yang bergerak. 4). Mekanisme adalah upaya memberikan penjelasan mekanis yakni dengan gerak setempat dari bagian yang secara intrinsik tidak dapat berubah bagi struktur internal benda alam dan bagi seluruh alam.

Pelayanan yang diperlukan manusia pada dasarnya terbagi atas dua jenis, yaitu layanan fisik yang sifatnya pribadi serta layanan administratif yang diberikan orang lain selaku anggota organisasi (organisasi massa atau organisasi negara). Berdasarkan pendapat tersebut yang dimaksud dengan pelayanan adalah kegiatan yang 
berkesinambungan dalam kehidupan sehari-hari yang berupa layanan fisik yaitu bersifat pribadi dan administratif yang biasa terdapat pada suatu kegiatan organisasi.

Menurut Joko Widodo (2001:131), pelayanan publik dapat dimaknai sebagai pemberian pelayanan (melayani) keperluan orang atau masyarakat yang mempunyai kepentingan pada organisasi sesuai dengan aturan pokok dan tata cara yang telah di tetapkan.

Berdasarkan keterangan diatas dari berbagai pengertian pelayanan dan pelayanan publik di atas dapat disimpulkan definisi pelayanan publik adalah pemberian pelayanan (melayani) yang dilaksanakan oleh penyelenggara pelayanan publik (pemerintah) sebagai upaya untuk pemenuhan kebutuhan dan keperluan penerima pelayanan atau masyarakat maupun pelaksana ketentuan peraturan perundang-undangan yang mempunyai kepentingan pada organisasi tersebut sesuai dengan aturan pokok dan tata cara yang telah di tetapkan. Kebutuhan dalam hal ini bukanlah kebutuhan secara individual akan tetapi berbagai kebutuhan yang sesungguhnya diharapkanmasyarakat.

Berdasarkan Undang-undang Republik Indonesia pasal 1 nomor 25 tahun 2009 tentang Pelayanan Publik, pengertian pelayanan publik adalah kegiatan atau rangkaian kegiatan dalam rangka pemenuhan kebutuhan pelayanan sesuai dengan peraturan perundang-undangan bagi setiap warga negara dan penduduk atas jasa, barang, dan/ atau pelayanan administratif yang disediakan oleh penyelenggara pelayanan publik.

Berdasarkan keterangan dari Undangundang Nomor 28 Tahun 2009, pada (pasal 7275), tentang Pajak Daerah dan Retribusi Daerah, maka dengan demikian untuk memperjelas mengenai aturan pendukung pemungutan pajak sarang burung walet adalah (1) Objek Pajak Sarang Burung Walet adalah pengambilan, pengusahaan Sarang Burung Walet. Artinya adalah mengenai benda yang kena pajak pada pengusaha sarang burung walet yaitu sarang burung walet yang di ambil di Goa yang ada di Daerah alam atau lobang-lobang batu yang ada di perbukitan atau tebing tebing pantai maupun yang dibuat Rumahan atau bangunan berupa sarang burung walet. (2) Tidak termasuk objek pajak sebagaimana dimaksud pada ayat satu adalah: a. pengambilan Sarang Burung Walet yang telah dikenakan Penerimaan Negara Bukan Pajak (PNBP); b. kegiatan pengambilan dan/atau pengusahaan Sarang Burung Walet lainnya yang ditetapkan dengan Peraturan Daerah. Subjek Pajak Sarang Burung Walet adalah orang pribadi atau Badan yang melakukan pengambilan dan/atau mengusahakan Sarang Burung Walet. Wajib Pajak Sarang Burung Walet adalah orang pribadi atau Badan yang melakukan pengambilan dan/atau mengusahakan Sarang Burung Walet. Dasar pengenaan Pajak Sarang Burung Walet adalah Nilai Jual Sarang Burung Walet. Nilai Jual Sarang Burung Walet sebagaimana dimaksud pada ayat satu dihitung berdasarkan perkalian antara harga pasaran umum Sarang Burung Walet berlaku di daerah yang bersangkutan dengan volume Sarang Burung Walet.

Tarif Pajak Sarang Burung Walet ditetapkan paling tinggi sebesar 10\% (sepuluh persen). Tarif Pajak Sarang Burung Walet ditetapkan dengan Peraturan Daerah. Besaran pokok Pajak Sarang Burung Walet yang terutang dihitung dengan cara mengalikan tarif pajak sarang burung walet, dengan dasar pengenaan pajak, Pajak Sarang Burung Walet yang terutang dipungut di wilayah daerah tempat pengambilan dan/atau pengusahaan Sarang Burung Walet. Berdasarkan keterangan dari Undang-undang Nomor 28 Tahun 2009, (pasal. 96-99). tentang Pajak Daerah dan Retribusi Daerah, Bab V Pemungutan Pajak, Bagian Kesatu Tata Cara Pemungutan. (1) Pemungutan Pajak dilarang diborongkan. (2) Setiap Wajib Pajak wajib membayar Pajak yang terutang berdasarkan surat ketetapan pajak atau dibayar sendiri oleh Wajib Pajak berdasarkan peraturan perundang-undangan perpajakan. (3) Wajib Pajak yang memenuhi kewajiban perpajakan berdasarkan penetapan Kepala Daerah dibayar dengan menggunakan SKPD (Surat Ketetapan Pajak Daerah, yang selanjutnya disingkat SKPD, adalah surat ketetapan pajak yang menentukan besarnya jumlah pokok pajak yang terutang) atau dokumen lain yang dipersamakan. (4) Dokumen lain yang dipersamakan berupa karcis dan nota perhitungan. (5) Wajib Pajak yang memenuhi kewajiban perpajakan sendiri dibayar dengan menggunakan SPTPD.

SPTPD (Surat Pemberitahuan Pajak Daerah), adalah surat yang oleh Wajib Pajak digunakan untuk melaporkan penghitungan pembayaran pajak, objek pajak, bukan objek pajak, harta dan kewajiban sesuai dengan ketentuan peraturan perundang-undangan perpajakan daerah). SKPDKB, dan/atau SKPDKBT (Surat Ketetapan Pajak Daerah Kurang Bayar Tambahan, yang selanjutnya disingkat SKPDKBT, adalah surat ketetapan pajak yang menentukan tambahan atas jumlah pajak yang telah ditetapkan). (1) Dalam jangka waktu 5 (lima) tahun sesudah saat terutangnya pajak, Kepala Daerah dapat menerbitkan: a. SKPDKB dalam hal: 1) jika berdasarkan hasil pemeriksaan atau keterangan lain, pajak yang terutang tidak atau kurang dibayar; 2) jika SPTPD tidak disampaikan kepada Kepala Daerah dalam jangka waktu tertentu dan setelah 
ditegur secara tertulis tidak disampaikan pada waktunya sebagaimana ditentukan dalam surat teguran; 3) jika kewajiban mengisi SPTPD (Surat Pemberitahuan Pajak Daerah, yang selanjutnya disingkat SPTPD, adalah surat yang oleh Wajib Pajak digunakan untuk melaporkan penghitungan dan/atau pembayaran pajak, objek pajak dan/atau bukan objek pajak, dan/atau harta dan kewajiban sesuai dengan ketentuan peraturan perundangundangan perpajakan daerah). tidak dipenuhi, pajak yang terutang dihitung secara jabatan. b. SKPDKBT (Surat Ketetapan Pajak Daerah Kurang Bayar Tambahan, yang selanjutnya disingkat SKPDKBT, adalah surat ketetapan pajak yang menentukan tambahan atas jumlah pajak yang telah ditetapkan). jika ditemukan data baru dan/ atau data yang semula belum terungkap yang menyebabkan penambahan jumlah pajak yang terutang. c. SKPDN (Surat Ketetapan Pajak Daerah Nihil, yang selanjutnya disingkat SKPDN, adalah surat ketetapan pajak yang menentukan jumlah pokok pajak sama besarnya dengan jumlah kredit pajak atau pajak tidak terutang dan tidak ada kredit pajak).

Jika jumlah pajak yang terutang sama besarnya dengan jumlah kredit pajak atau pajak tidak terutang dan tidak ada kredit pajak. (2) Jumlah kekurangan pajak yang terutang dalam SKPDKB, dikenakan sanksi administratif berupa bunga sebesar 2\% (dua persen) sebulan dihitung dari pajak yang kurang atau terlambat dibayar untuk jangka waktu paling lama 24 (dua puluh empat) bulan dihitung sejak saat terutangnya pajak. (3) Jumlah kekurangan pajak yang terutang dalam SKPDKBT, dikenakan sanksi administratif berupa kenaikan sebesar 100\% (seratus persen) dari jumlah kekurangan pajak tersebut. (4) Kenaikan tidak dikenakan jika Wajib Pajak melaporkan sendiri sebelum dilakukan tindakan pemeriksaan. (5) Jumlah pajak yang terutang dalam SKPDKB dikenakan sanksi administratif berupa kenaikan sebesar 25\% (dua puluh lima persen) dari pokok pajak ditambah sanksi administratif berupa bunga sebesar 2\% (dua persen) sebulan dihitung dari pajak yang kurang atau terlambat dibayar untuk jangka waktu paling lama 24 (dua puluh empat) bulan dihitung sejak saat terutangnya pajak. Ketentuan lebih lanjut mengenai jenis Pajak yang dapat dipungut berdasarkan penetapan Kepala Daerah atau dibayar sendiri oleh Wajib Pajak dan ketentuan lainnya berkaitan dengan pemungutan Pajak diatur dengan Peraturan Pemerintah.

Dalam melakukan penelitian, berbagai macam metode dapat digunakan. Dalam penelitian ini digunakan jenis penelitian kualitatif. Jenis penelitian kualitatif menurut Kirk dan Miller (Moleong, 2012:2), "pada mulanya bersumber pada pengamatan kualitatif yang dipertentangkan dengan pengamatan kuantitatif. Pengamatan kuantitatif melibatkan pengukuran tingkatan suatu ciri tertentu." Sementara itu menurut Denzin dan Lincoln (Moleong, 2012:3), Penelitian kualitatif adalah penelititan yang menggunakan latar alamiah, dengan maksud menafsirkan fenomena yang terjadi dan dilakukan dengan jalan melibatkan berbagai metode yang ada."

Prosedur pemecahan masalah yang di selidiki dengan menggambarkan /melukiskan keadaan subjek/objek penelitian (seseorang, keluarga, masyarakat dan lain-lain). Tujuan penelitian deskriptif adalah untuk membuat deskripsi, gambaran atau lukisan secara sistematis. Dalam penelitian deskriptif ini, penulis ingin mendeskripsikan Pelayanan Pembayaran Pajak Sarang Burung Walet di Kantor BAPPENDA (Badan Pengelolaan Pendapatan Daerah) Kabupaten Sintang. serta melihat faktor-faktor yang mempengaruhi Pelayanan Pembayaran Pajak Sarang Burung Walet di Kantor BAPPENDA (Badan Pengelolaan Pendapatan Daerah) Kabupaten Sintang.

Subjek penelitian dalam penelitian ini berjumlah empat orang, meliputi : a. Kepala Kantor Badan Pengelolaan Pendapatan Daerah Kabupaten Sintang. b. Pegawai Bidang Pendataan Pajak Sarang Burung Walet di BAPPENDA. c. Pegawai Pelayanan Penerima Pajak. d.Subjek Pajak/Pembayar Pajak.

Teknik Pengumpulan Data. Pengumpulan data pada penelitian kualitatif membutuhkan teknikteknik kualitatif pula. Menurut Bungin, (2012:243), mengatakan: "Pada umumnya dalam penelitian kualitatif, peneliti dapat memilih beberapa teknik pengumpulan data antara lain: (1). Oservasi partisipasi atau nonpartisipan; (2). Wawancara; (3). Analisis dokumen. (4). Catatan harian peneliti (rekaman pengalaman dan kesan penliti pada saat pengumpulan data."

\section{HASIL PENELITIAN DAN PEMBAHASAN}

Paradigma baru dalam sistem penyelenggaraan pemerintahan dari pola sentralisasi menjadi pola desentralisasi membawa implikasi yang mendasar terhadap keberadaan, tugas, fungsi dan tanggungjawab lembaga serta aparatur pemerintah di daerah dalam mewujudkan penyelenggaraan pemerintahan yang didasarkan pada prinsip-prinsip good governance. Sebagai konsekuensinya adalah, diperlukan aparatur pemerintah yang demokratis, netral, profesional, memiliki kompetensi, bersih, dan tanggap terhadap aspirasi masyarakat dan perubahan.

Mekanisme Pelayanan Pengurusan dan Pelayanan Pajak Sarang Burung walet di Kabupaten Sintang di Lakukan Oleh Kantor BAPPENDA, dalam melakukan penarikan Pajak 
sarang burung walet yang ada di Kabupaten Sintang Pihak Kantor BAPPENDA mesti berkerja sama dengan Instansi terkait.

Gambar 1 Gambar Mekanisme Pengurusan dan Pelayanan Pajak Sarang Burung Walet Pada Kantor BAPPENDA Kabupaten Sintang, di dasarkan pada Peraturan Bupati Sintang. Nomor 28 Tahun 2016, tentang Tatacara Pemungutan Pajak Sarang Burung Walet Tahun 2018.

Wajib Pajak

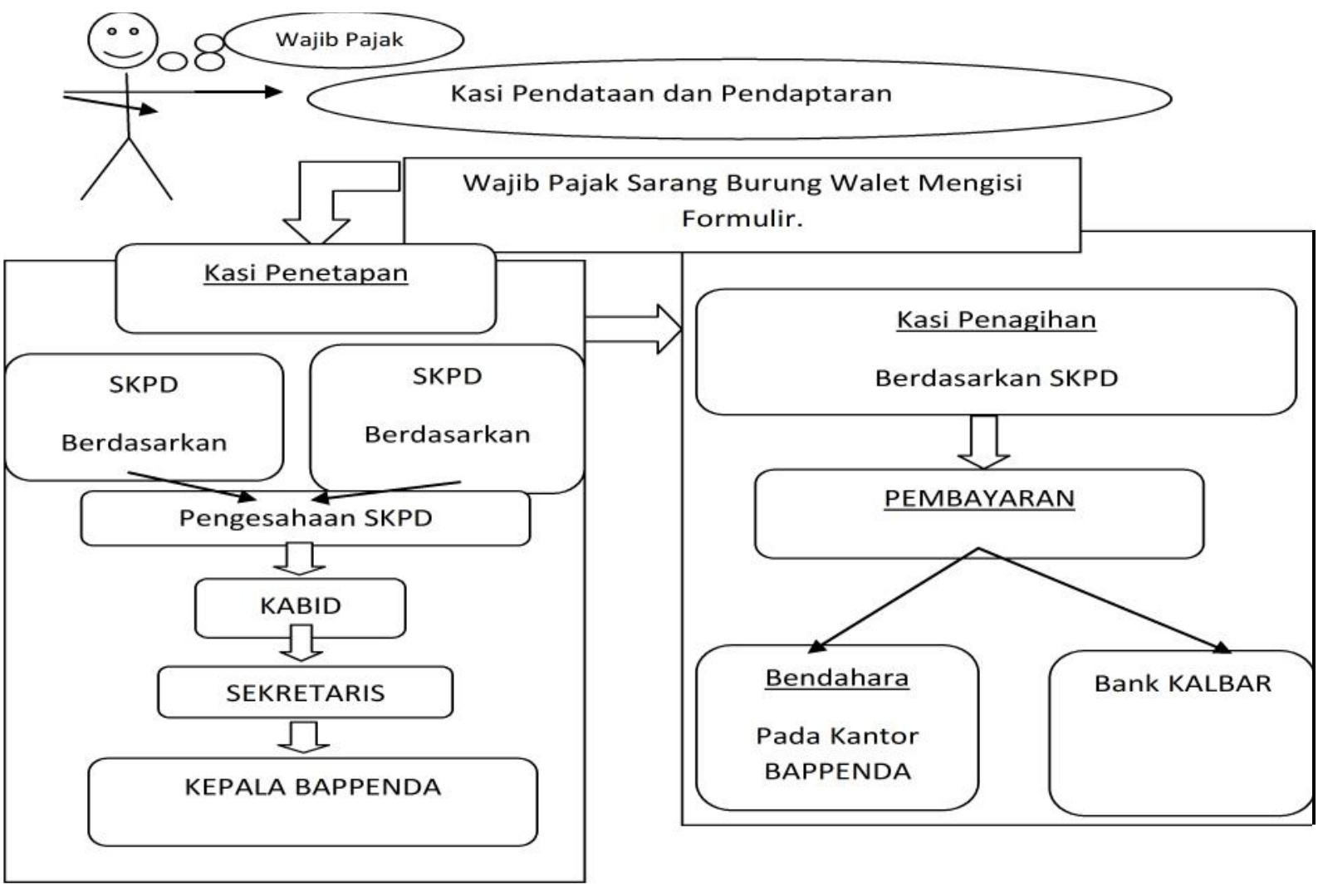

Sumber : Kantor BAPPENDA Kabupaten Sintang.

Tahun 2019

Keterangan Gambar1 : Mekanisme Pelayanan Pembayaran Pajak Sarang Burung Walet pada Kantor Badan Pengelolaan Pendapatan Daerah Kabupaten Sintang, Pada saat Kedatangan Wajib Pajak Sarang Burung Walet di Kantor BAPPENDA Kabupaten Sintang, Wajib Pajak Sarang Burung Walet bisa langsung menanyakan pada bagian Informasi (loket informasi), tentang maksud dan tujuannya apa bila sudah di jelaskan maka kepada Wajib Pajak Sarang Burung Walet bisa langsung di antar oleh petugas pada Kasi Pendataan dan Pendaptaran selanjutnya Wajib Pajak Sarang Burung Walet Mengisi Formulir Pendaptaran SPOPD ( Surat Pendaftaran Objek Pajak Daerah). Yang di maksud dengan SPOPD adalah surat yang di gunakan wajib pajak untuk mendaftarkan diri dan melaporkan usahanya atau objek pajak ke Kantor Badan Pengelolaan Pendapatan Daerah Kabupaten Sintang. untuk memperjelas mengenai Mekanisme Pelayanan Pembayaran pajak sarang burung walet yang di lakukan oleh Kantor Badan Pengelolaan Pendapatan Daerah Kabupaten Sintang maka
Penulis bisa berpegang pada Peraturan Bupati Sintang Nomor 28 Tahun 2016. Tentang Tatacara Pemungutan Pajak Sarang Burung Walet.

Bagian Pertama Pendaftaran setiap penyelengara sarang burung walet wajib mendaftarkan dirinya dan melaporkan usahanya dengan media SPOPD atau Surat Pendaftaran Objek Pajak Daerah. Pdaftaran Penyelengaraan sarang burung walet, setelah para pemilik sarang burung walet mendirikan bangunan sarang burung walet dan telah selesai menata juga melengkapi segala sesuatu yang berkenaan dengan penyiapan bangunan yang akan di gunakan untuk menampung sarang burung walet maka paling lama Tujuh hari setelah kegiatan di mulai para pemilik sarang burung walet wajib melaporkan kegiatanya pada bagian Kasi Pendaftaran dan Pendataan sarang burung walet.

Tatacara Pendaftaran dan Pendataan Dasar Pengenaan Pajak adalah nilai jual sarang burung walet. Nilai jual merupakan hasil perkalian antara volume produksi dengan harga standar yang ditetapkan Bupati. Maka melalui Keputusan Bupati 
174. Fokus, Volume 18, Nomor 2, September 2020, hlm. 169 - 176

Sintang Nomor 970/2/KEP-DISPENDA/2017. Tentang penetapan harga pasaran umum sarang burung walet di Kabupaten Sintang. Tertanggal 3 Januari 2017.

Tabel 1 Daftar harga pasaran umum sarang burung walet di Kabupaten Sintang., Tahun 2018

\begin{tabular}{|l|l|c|c}
\hline NO & \multicolumn{1}{|c|}{$\begin{array}{c}\text { JENIS SARANG BURUNG } \\
\text { WALET }\end{array}$} & $\begin{array}{c}\text { KLASIFIKASI } \\
\text { SARANG BURUNG } \\
\text { WALET }\end{array}$ & $\begin{array}{c}\text { HARGA SARANG } \\
\text { BURUNG WALET } \\
\text { PERKILO GRAM } \\
(\mathrm{Rp})\end{array}$ \\
\hline 1. & Sarang Burung Walet Mangkok & Klasifikasi A & $6.000 .000,00$ \\
\hline 2. & Sarang Burung Walet Sudut & Klasifikasi B & $4.000 .000,00$ \\
\hline 3. & Sarang Burung Walet Retakan & Klasifikasi C & $2.000 .000,00$ \\
\hline
\end{tabular}

Sumber : Kantor Badan Pengelolaan Pendapatan

Daerah Kabupaten Sintang, Tahun, 2019

Kegiatan pendataan usaha sarang burung walet sebagai objek pajak sekaligus pendataan pemilik/penanggung jawab usaha sarang burung walet sebagai wajib pajak juga melibatkan pihak ketiga seperti Badan Pusat Statistik (BPS) Kabupaten Sintang. Pendataan yang dilakukan sudah meliputi data utama seperti jenis bangunan, lokasi tempat usaha, luas bangunan, tahun mulai beroperasi, pemilik/penanggung jawab usaha dan alamat pemilik/penanggung jawab usaha. Data yang dihasilkan tidak memberikan informasi tentang luas bangunan rumah walet, serta sebagian usaha sarang burung walet belum diketahui nama dan alamat pemilik/penanggung jawab usahanya.

Data dan informasi yang dihasilkan dari kegiatan pendataan usaha sarang burung walet ini nantinya akan digunakan sebagai dasar bagi Kantor Badan Pengelolaan Pendapatan Daerah Kabupaten Sintang untuk mendaftarkan usaha wajib pajak, apabila wajib pajak tidak mendaftarkan sendiri usahanya, sebagaimana yang telah diatur dalam Peraturan Bupati Sintang Nomor 28 Tahun 2016. Tentang Tatacara Pemungutan Pajak Sarang Burung Walet. yang berpedoman pada undang undang perpajakan daerah serta sistem dan prosedur pajak daerah.

Proses pemungutan pajak sarang burung walet yang diatur dalam Peraturan Bupati Kabupaten Sintang, dilakukan melalui tahapan seperti yang telah dijelaskan pada halaman sebelumnya dalam hasil penelitian dapat dilihat pada Bagian Mekanisme Pelayanan. Dari rangkaian proses pemungutan pajak sarang burung walet seperti yang terlihat pada bagian tsb menjelaskan bagaimana mekanisme pengelolaan pemungutan pajak daerah khusus pajak sarang burung walet yang dilakukan oleh Kantor Badan Pengelolaan Pendapatan Daerah Kabupaten Sintang.

Upaya yang telah dilakukan Pemerintah Kabupaten Sintang dalam rangka pemungutan pajak sarang burung walet diantaranya dengan

melakukan sosialisasi tentang pajak sarang burung walet dan tata cara pengurusan izin usaha sarang burung walet, Kemudian Kantor Badan Pengelolaan Pendapatan Daerah Kabupaten Sintang mengeluarkan Surat Perintah Tugas. Surat Perintah Tugas tersebut ditujukan kepada Tim Intensifikasi Sumber-sumber Penerimaan Pendapatan Asli Daerah (PAD) dalam rangka pemutakhiran data potensi pajak daerah Pemerintah Kabupaten Sintang.

Target Nilai penerimaan pajak sarang burung walet di Kabupaten Sintang, dalam Tahun 2018 adalah sebesaar Rp. 60.928.000,-/tahun, dengan jumlah wajib pajak sarang burung waletnya sebanyak 125 Orang Pengusaha, dan dengan rincian jenis sarang burung walet Sudut sebanyak 100 , Orang Pengusaha, jenis sarang burung walet Mangkok sebanyak 3 orang pengusaha, Jenis sarang burung walet Retakan sebanyak 2 orang pengusaha, selanjutnya Tahun 2019, adalah sebesar Rp.7.592.000. dengan 10 orang wajib pajak sampai dengan bulan Maret 2019.tertanggal 26 Maret 2019. karena untuk pajak sarang burung walet masih tergolong kecil dibanding pajak-pajak yang lain. Nilai penerimaan untuk saat ini sudah memenuhi target penerimaan pajak sarang burung walet yang telah ditetapkan Pemerintah Kabupaten Sintang. Dengan kata lain, target penerimaan pajak sarang burung walet yang telah ditetapkan Pemerintah Kabupaten Sintang sudah tercapai untuk bisa membantu penerimaan daerah.

Sumber daya manusia yang ada pada Kantor Badan Pengelolaan Pendapatan Daerah Kabupaten Sintang, dapat dilihat dalam Struktur organisasi Kantor Badan Pengelolaan Pendapatan Daerah Kabupaten Sintang. Mengenai sumber daya manusia yang ada pada Kantor Badan Pengelolaan Pendapatan Daerah Kabupaten Sintang telah sesuai dengan Keahlianya masingmasing yang di dasarkan pada Tugas Pokok dan Fungsi Masing-masing. Pada bidang pengembangan memiliki tugas antara lain: 1 . 
Membuat rencana kegiatan Bidang Pengkajian dan Pengembangan. 2. Mengkoordinir para Kepala Seksi. 3.Memberi petunjuk kepada Kepala Seksi dan bawahan. 4. Menilai hasil kerja Kepala Seksi dan bawahan. 5. Melaksanakan pengkajian potensi dalam rangka pengembangan obyek pendapatan daerah.6.Melaksanakan pengkajian dan pengembangan rencana pendapatan daerah. 7 . Melaksanakan pengkajian, penyusunan pra rancangan peraturan daerah bidang pendapatan daerah. 8. Mengkoordinasikan pelaksanaan sosialisasi peraturan perundang-undangan dan informasi lainnya bidang pendapatan daerah.9.Melaporkan hasil pelaksanaan tugas kepada Kepala Dinas Pendapatan. 10. Melaksanakan tugas kedinasan lainnya yang diberikan oleh atasan.

Selanjutnya pada Bidang Pendataan dan Penetapan mempunyai tugas pokok merumuskan dan melaksanakan kebijakan teknis penggalian potensi pendapatan daerah melalui upaya intensifikasi dan ekstensifikasi, penyusunan rencana pendapatan asli daerah, bagi hasil dan lain -lain, pendapatan daerah yang sah, pelaksanaan evaluasi terhadap potensi pendapatan daerah dan pengelolaan sistem informasi pendapatan daerah, melaksanakan pelayanan dan penetapan, perhitungan, penerbitan ketetapan pajak daerah dan retribusi daerah yang terutang serta penatausahaan Surat Pemberitahuan Pajak Terutang (SPPT) dan Daftar Himpunan Ketetapan Pembayaran (DHKP) PBB P2.

Bidang Pengolahan Data dan Informasi : 1.Menyusun rencana dan laporan kegiatan seksi pengembangan system informasi. 2. Memfasilitasi pengolahan system informasi manajamen pendapatan daerah. 3. Melakukan pembinaan dan perumusan pengembangan system informasi. 4 .

Melakukan pekerjaan/kegiatan penyiapan bahan perumusan teknis dibidang pengembangan system pelayanan. 5. Melaksanakan evaluasi terhadap system informasi. 6. Melaksanakan tugas lain-lain yang diberikan oleh atasan langsung terutama pelaksanaan tugas yang sifatnya mendesak dan penting, atau pelaksanaan tugas yang berhubungan dengan Pengolahan data dan Informasi.

Penarikan pajak sarang burung walet di Kabupaten Sintang terutama yang di lakukan oleh Kantor Badan Pengelolaan Pendapatan Daerah Kabupaten Sintang dan yang berhubungan dengan sumber daya manusia yang ada sudah cukup baik artinya mereka telah bekerja sesuai dengan harapan Masyarakat dan Pemerintah sendiri sebagai pelaksana dan pemberi layanan tentang penarikan dan pengelolaan pendapat daerah melalui sektor pajak yang akan di pergunakan untuk membiaya pelaksanaan pembangunan di Kabupaten Sintang.

\section{KESIMPULAN DAN SARAN}

Mekanisme Pelayanan telah diatur dan di dasarkan pada Peraturan Bupati Sintang. Nomor 28 Tahun 2016, tentang Tatacara Pemungutan Pajak Sarang Burung Walet dan telah berjalan sesuai dengan aturan dan Petunjuk yang ada dan selalu mendapat pengawasan baik langsung maupun tidak langsung atau melalui kepala seksi masing-masing. Tatacara Pendaftaran dan Pendataan, Pihak Kantor BAPPENDA Kabupaten Sintang tidak membentuk Lembaga atau Bagian Khusus Penarikan Pajak Sarang Burung Walet Petugas hanya di bekali oleh surat Tugas, artinya Kantor BAPPENDA tidak memiliki stuktur khusus untuk Penarikan Pajak Sarang Burung Walet tapi melalui Bagian Penarikan Pajak secara Umum Termasuk Galian Sumur dan Lainya. Sumber Daya Manusia, adalah mereka yang telah memiliki kualitas Khusus dalam penangan penarikan pajak sarang burung walet yang ada di Kabupaten Sintang Secara Keseluruhannya. Berdasarkan Hasil Penelitian diatas tentang Pelayanan Pembayaran Pajak Sarang Burung Walet di Kantor Badan Pengelolaan Pendapatan Daerah Kabupaten Sintang, dapat di saran bahwa : Agar Mekanisme Pelayanan Penarikan Pajak sarang burung walet di Kabupaten Sintang dapat berjalan sesuai dengan yang di harapkan maka Kepala Badan Pengelolaan Pendapatan Daerah Kabupaten Sintang, dapat bekerja sama dengan Instansi terkait, agar dapat meningkatkan pendapatan pajak Daerah pada bidang pengusahaan sarang burung walet. Tatacara Pendaftaran dan Pendataan yang sudah baik agar di tingkatkan lagi supaya masyarakat memiliki minat untuk membayar sendiri kewajiban pajaknya, pada Kantor Badan Pengelolaan Pendapatan Daerah Kabupaten Sintang. Sumber Daya Manusia yang ada pada Kantor Badan Pengelolaan Pendapatan Daerah Kabupaten Sintang perlu untuk di tingkatkan lagi melaui Pendidikan dan Pelatihan Pegawai, juga perlu di lakukan terus menerus guna peningkatan Kualitas Pelayanan Publik di Wilayah Kabupaten Sintang.

\section{DAFTAR PUSTAKA}

Jackson, E., Schuler, Randall S., dan Werner, Steve. 2010. Pengelolaan Sumber Daya Manusia. Buku 1ed. 10. Jakarta: Salemba Empat.

Mathis, Robert L., dan Jackson, John H. 2009. Manajemen Sumber Daya Manusia. Ed. 10 Dialihbahasakan oleh Diana Angelica. Jakarta: Salemba Empat.

Moleong, L. J. 1999. Metodologi Penelitian Kualitatif. Bandung : PT RemajaRosdakarya. 
176. Fokus, Volume 18, Nomor 2, September 2020, hlm. 169 - 176

Widodo, Joko. 2001. Good Governance: Telaah dari Dimensi: Akuntabilitas dan Kontrol Birokrasi pada Era Desentralisasi dan Otonomi Daerah. Insan Cedekia. Surabaya.

\section{Peraturan Perundang-undangan,}

Negara Republik Indonesia, 2007. KEPUTUSAN MENPAN No. 63 Tahun 2003 tentang Penyelenggaraan Pelayanan

Negara Republik Indonesia, 2009. Undang-undang No. 25 Tahun 2009 tentang Komponen Standar Pelayanan.

Negara Republik Indonesia, 2014. Undang-undang No. 15 Tahun 2014, tentang Standar Pelayanan.
Negara Republik Indonesia, 2004. Undang-Undang Republik Indonesia Nomor 33 Tahun 2004 Tentang Perimbangan Keuangan Pusat dan Daerah

Negara Republik Indonesia, 2016. PERBUB SINTANG No. 28 Tahun 2016 tentang Tatacara pemungutan pajak sarang burung walet.

Negara Republik Indonesia, 2017. Keputusan Bupati Sintang.No.970 Tahun 2017 tentang Penetapan Harga pasaran umum sarang burung walet di Sintang. 